\title{
"Retomada da educação escolar": \\ Um estudo sobre educação, território e poder na experiência Pankará
}

MENDONÇA, Caroline Farias Leal ${ }^{1}$

\section{RESUMO}

O povo Pankará da Serra do Arapuá, localizada no Sertão de Pernambuco, deflagra um movimento chamado "Retomada da Educação" no ano de 2004. Desde então, a escola é apropriada como uma importante estratégia pedagógica para a formação, politização, mobilização e organização do povo face a antagonistas históricos. $O$ artigo tem como objetivo refletir como a categoria política "retomada" é apropriada pelos Pankará na luta pela educação escolar e quais sentidos atribuem a ela. O texto inicia com um breve histórico da formação social na Serra do Arapuá e da resistência dos Pankará. Em seguida traz a descrição etnográfica da Retomada da Educação como um projeto que articula Território e Poder. Por fim, o texto analisa o Projeto Político Pedagógico que nasce das experiências comunitárias dos indígenas com seus parentes do quilombo-indígena Tiririca dos Crioulos, evidenciando os modos de fazer, conteúdos e intencionalidades presentes neste projeto específico de escola.

Escola Indígena. Retomada. Pankará. Tiririca dos Crioulos.

\section{"Resumption of School education": A study on education, territory and power in the Pankará experience}

\section{ABSTRACT}

The Pankará people of Serra do Arapuá, located in the Pernambuco backlands, set off a movement called "Retaking of Education" in 2004. Since then, the school has been appropriate as an important pedagogical strategy for the formation, politicization, mobilization and organization of the people against their historical antagonists. The article aims to reflect how the "retaking" political category is appropriated by the Pankará in the struggle for school education and what meanings they attribute to it. The text begins with a brief history of social formation in the Serra do Arapuá and the resistance of the Pankará, followed by the ethnographic description of the Resumption of Education as a

${ }^{1}$ Doutora em Antropologia pela Universidade Federal de Pernambuco (UFPE). Professora Adjunta da Universidade da Integração Internacional da Lusofonia Afro-Brasileira (Unilab-CE), Instituto de Humanidades, Curso de Antropologia. Coordenadora o Grupo de Estudos com Povos Indígenas.

E-mail: carolineleal@unilab.edu.br. Lattes: http://lattes.cnpq.br/9385074996173582.

Orcid: https://orcid.org/0000-0001-6303-7984.

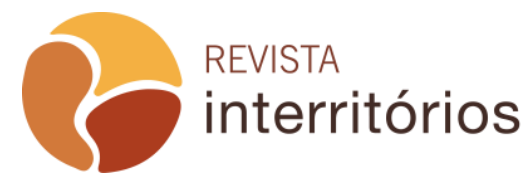

Interritórios | Revista de educação Universidade Federal de Pernambuco, Caruaru, BRASIL | V.6 N.9 [2019] 
project that articulates Territory and Power. Finally, the text analyzes the Pedagogical Political Project that is born from the community experiences of the indigenous with their relatives of the Quilombo-indigenous Tiririca dos Crioulos, highlighting the ways of doing, contents and intentionalities present in this specific school project.

Indian School. Retaking. Pankará. Creole Tiririca.

\section{"Ripresa dell'istruzione scolastica": uno studio sull'educazione, il territorio e il potere nell'esperienza di Pankará}

\section{RIASSUNTO}

II popolo Pankará di Serra do Arapuá, situato in Pernambuco, Brasile, nel 2004 ha avviato un movimento chiamato "Ripresa dell'educazione". Da allora, la scuola è stata appropriata come importante strategia pedagogica per la formazione, la politicizzazione, la mobilitazione e l'organizzazione di persone di fronte agli antagonisti storici. L'articolo ha lo scopo di riflettere su come la categoria politica "ripresa" viene appropriata dal popolo Pankará nella lotta per l'istruzione scolastica e quali significati attribuiscono ad essa. II testo inizia con una breve storia della formazione sociale nella Serra do Arapuá e la resistenza del Pankará. Poi arriva la descrizione etnografica della Ripresa dell'educazione come progetto che articola Territorio e Potere. Infine, il testo analizza il Progetto politico pedagogico che nasce dalle esperienze della comunità degli indigeni con i loro parenti della Tiririca dos Crioulos Quilombo-indigena, evidenziando il modo di fare, i contenuti e le intenzioni presenti in questo specifico progetto scolastico.

Scuola indiana. Ripresa. Pankará. Creole Tiririca.

\section{Reanudación de la Educación Escolar: un estudio sobre educación, territorio y poder en la experiencia Pankará}

\section{RESUMEN}

El pueblo Pankará de Serra do Arapuá, ubicado en el sertão de Pernambuco, empieza un movimiento llamado "Retomada da Educação" en 2004. Desde entonces, la escuela ha sido apropiada como una estrategia pedagógica importante para la formación, politización, movilización y organización del pueblo frente a antagonistas históricos. El artículo tiene como objetivo reflejar cómo los Pankará se apropian de la categoría política "reanudación" en la lucha por la educación escolar y qué significados le atribuyen. El texto comienza con una breve historia de la formación social en la Serra do Arapuá y la resistencia de los Pankará. Luego viene la descripción etnográfica de la Reanudación de la Educación como un proyecto que articula Territorio y Poder. Finalmente, el texto analiza el Proyecto Político Pedagógico que nace de las experiencias comunitarias de los indígenas con sus familiares de lo quilombo-

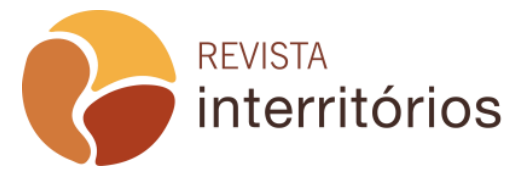


"Retomada da Educação Escolar": um estudo sobre

indígena Tiririca dos Crioulos, destacando las formas de hacer, los contenidos y las intenciones presentes en este proyecto escolar específico.

Escuela Indígena. Reanudación. Pankará. Tiririca dos Crioulos.

\section{INTRODUÇÃO}

Sertão é onde o pensamento da gente se forma mais forte do que o poder do lugar

Guimarães Rosa².

Eu estava lá, atrás da pedra. Vivia lá.

Só olhava o mundo de butuca,

saia de pouquinho, olhava tudo e voltava. Eu saí. Agora, estou aqui ocupando o Palácio do Planalto com meus parentes, lutando pelos direitos dos índios [Abril Indígena, DF 2013]. Veja que coisa... Saí de trás da pedra e agora estou aqui. O povo Pankará não volta nunca mais para de trás da pedra (risos).

Pajé Pedro Limeira, 2013.

Acompanhar a trajetória do povo Pankará é uma experiência que tem me conduzido a compreender o Sertão mais como território epistemológico, indo além dos aspectos geográficos e políticos. Se, para os colonizadores, o Sertão caracterizou-se como espaço de conquista, para os indígenas caracterizou-se como um espaço de resistência. É neste Sertão, abrigo de transmutações históricas e políticas provocadas no confronto ao processo colonizador, que os Pankará constroem a sua identidade de povo. Lutam por seu território, o concebem de maneira coletiva e formulam um projeto de educação escolar situado na historicidade do grupo.

O povo Pankará toma por seu território tradicional a Serra do Arapuá, localizada no município de Carnaubeira da Penha ${ }^{3}$, geopolítica do Sertão do São Francisco pernambucano. Segundo recenseamento da organização de professoras indígena (2010), a população é de 4.716 pessoas, distribuídas em torno de 52 aldeias.

Conheci o povo em 1999 e naquele contexto não estavam mobilizados pela reivindicação de direitos como indígenas, conforme tratei em estudo anterior de mestrado (MENDONÇA, 2003). Compartilhavam de uma memória

\footnotetext{
${ }^{2}$ ROSA, João Guimarães. Grande Sertão Veredas. Rio de Janeiro: Nova Fronteira, 2001.

${ }^{3}$ O município de Carnaubeira da Penha é o antigo "Sítio da Penha" que aparece nas fontes históricas dos séculos XVIII e XIX como área de disputa territorial entre os indígenas, a igreja e o legislativo municipal. Foi distrito do município de Floresta ${ }^{3}$, sendo elevada à categoria de

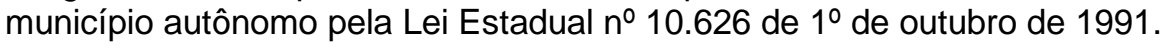

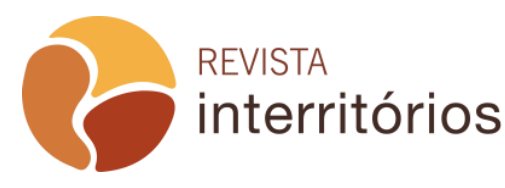


coletiva em circuitos rituais de Toré e processos de resistência vividos entre os anos de 1940 e 1960, período da presença do Serviço de Proteção ao Índio (SPI) na região. A pesquisa etnográfica me possibilitou conhecer a cosmografia ${ }^{4}$ Pankará por meio das redes de parentesco, da concepção de uso coletivo da terra e da territorialidade assentada em saberes espirituais e ambientais particulares.

No ano de 2003, a nova geração de lideranças Pankará, filhos/as e netos/as das lideranças que acionaram o SPI, se reorganiza politicamente e delibera sobre tornar pública a identidade coletiva. É deflagrado um novo período histórico de lutas por direitos, agora, sob o etnonimo Pankará.

A questão da educação surge como interesse de investigação etnográfica durante pesquisa de campo, entre os anos 2010 e 2012, para o doutoramento. Era meu objetivo compreender a formação social e histórica da Serra do Arapuá pelos Pankará e sua gestão territorial compartilhada entre os indígenas e seus parentes do quilombo-indígena Tiririca dos Crioulos ${ }^{5}$. Durante as entrevistas com lideranças, perguntei para a cacique Dorinha quais processos conduziram os "caboclos da Serra do Arapuá" à retomada da luta como povo indígena. E a cacique respondeu: - você quer saber como foi a Retomada da Educação?

Compreendi que, para os Pankará, a insurgência política desencadeada neste período recente da história, mesmo sendo um fenômeno processual, teve um marco simbólico, que é o movimento denominado "Retomada da Educação". Afinal, como afirma Eric Wolf (2003), nem nações tampouco entidades étnicas são criações primordiais; ambas são construídas em condições sociais, econômicas e políticas historicamente definíveis. Por conseguinte, a luta pela escola indígena foi incorporada à análise e se tornou uma via analítica indispensável à cartografia social dos conflitos vividos pelo povo na atualidade e na compreensão dos seus anseios de descolonização das relações de poder na Serra do Arapuá.

A Retomada da Educação ocorreu no ano de 2004 e, de forma abreviada, pode ser definida como uma decisão coletiva de se posicionar como povo para defender a autonomia de deliberar sobre o projeto de futuro e de

\footnotetext{
${ }^{4}$ Segundo Paul Little (2002, p.4) "A cosmografia de um grupo inclui seu regime de propriedade, os vínculos afetivos que mantém com seu território específico, a história da sua ocupação guardada na memória coletiva, o uso social que dá ao território e as formas de defesa dele". ${ }^{5} \mathrm{O}$ quilombo-indígena Tiririca dos Crioulos é formado a partir da relação histórica e de parentesco com o povo Pankará da Serra do Arapuá. Possuem territórios contínuos e fazem parte de uma mesma organização sociopolítica, conforme discutiremos neste artigo. Para mais informações sobre o quilombo-indígena ver: Mendonça (2013); o vídeo "Tiririca dos Crioulosum quilombo índigena" disponível em: https://www.youtube.com/watch?v=cpsGRfK0Bmk. Acesso em 30 set.2019.; e o livro de autoria coletiva das professoras e lideranças intitulado " Um quilombo-indígena: Tiririca dos Crioulos", disponível em: https://racismoambiental.net.br/2016/02/27/tiririca-dos-crioulos-um-quilombo-indigena-para-nospresentes-para-a-comunidade-reconhecimento-e-justica/. Acesso em 30 set.2019.
}

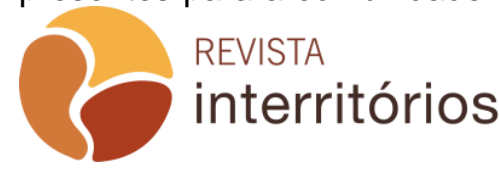


gestão territorial por intermédio da luta pela escola indígena. Como será argumentado neste artigo, a escola indígena é apropriada como uma importante estratégia pedagógica para a formação, politização, mobilização e organização do povo face a seus antagonistas históricos. Nesse sentido, a escola converte-se em um projeto que se desenvolve numa intrínseca relação entre Educação, Território e relações de Poder.

Nas lutas indígenas, as retomadas são importantes estratégias coletivas para a recuperação de áreas de seus territórios que se encontram em posse de não índios (ALARCON, 2013). Devido sua característica autonomista em busca do bem coletivo, representam uma prática organizativa com grande capacidade de mobilização interna e contribuem para processos de descolonização das relações de poder entre os índios e seus opressores. O caso Pankará possibilita um interessante estudo etnográfico ao transpor a categoria Retomada, geralmente utilizada na luta territorial, para conceber e organizar a luta no âmbito da educação escolar.

A princípio esta transposição pode soar inadaptada, considerando que, diferentemente do território, a escola é uma instituição estatal e a história da educação formal para os povos indígenas no Brasil encontra-se associada ao legado colonial. A história dos projetos educacionais direcionados aos indígenas tem origem com o propósito claro de epistemicídio, um fenômeno "mais vasto que o genocídio porque ocorreu sempre que se pretendeu subalternizar, subordinar, marginalizar ou ilegalizar práticas e grupos sociais que podiam ameaçar a expansão capitalista" (Santos, 1995, p.328). Ou seja, foram importantes estratégias de colonização e estavam estruturados em duas bases eurocêntricas: a salvacionista cristã, que implicava na evangelização para "humanizar o gentio", e a civilizatória, que significou as tentativas de destruição dos modos de vida plurais, considerados inferiores para os padrões racistas do colonizador branco. De tal modo que me coube refletir como essa categoria política Retomada é apropriada pelos Pankará na luta pela educação escolar. Quais sentidos atribuem a ela? Qual a sua importância? E mais: como este estudo colabora para a reflexão teórica e empírica sobre os projetos de educação escolar indígena?

Busco refletir sobre tais questões ao passo que este artigo também examina, por meio da etnografia, como o povo Pankará lança mão da educação para a desobediência e, desobedecendo, reinventa a vida na Serra do Arapuá. Os dados aqui reunidos compõe parte da minha tese ${ }^{6} \mathrm{e}$ ao longo do texto pretendo demonstrar como para os Pankará a noção de escola indígena, subjacente ao seu Projeto Político Pedagógico, é construída de forma interseccional cruzando as vias da sua experiência histórica com as demandas

${ }^{6}$ Defendida no ano de 2013 no Programa de Pós-Graduação em Antropologia na UFPE. 
contemporâneas de politização do povo, necessárias ao processo em curso de descolonização das relações de poder, do ser e do saber.

Para o desenvolvimento do argumento aqui apresentado me apoio na produção teórica das professoras Pankará e do quilombo-indígena Tiririca dos Crioulos ${ }^{7}$, além dos estudos decoloniais, com destaque para os autores Quijano (2005); Fanon (2010) e as autoras Segato (2012) e Walsh (2009). O texto inicia com um breve histórico da formação social na Serra do Arapuá e dos processos de resistência dos Pankará para situar o contexto mais amplo da colonialidade que se estruturou na região estudada. Em seguida, apresento uma descrição etnográfica da Retomada da Educação, buscando evidenciar a perspectiva indígena, dando ênfase às lutas empreendidas na defesa do território, na busca da autonomia e no direito a existir enquanto povo com seus consensos e dissensos internos. Por fim, o texto aborda as experiências comunitárias dos Pankará, os modos de fazer, conteúdos e intencionalidades presentes no Projeto Político Pedagógico e nas práticas que sustentam tal projeto específico de escola.

\section{Os Pankará na Serra do Arapuá}

Os Pankará reivindicam seu direito territorial (Serra do Arapuá) ao Estado brasileiro desde a década de 1940, no mesmo período dos seus vizinhos, o povo Atikum ${ }^{8}$. O histórico de ocupação da Terra Indígena, de acordo com a memória dos Pankará, está diretamente relacionado à luta por direitos travada pelos índios que permaneceram na Serra do Arapuá às custas de grandes conflitos com os fazendeiros da região e com o órgão indigenista oficial, o SPI.

A afirmativa é possível porque documentos do SPI, arquivados no Museu do Índio, apresentam sucessivas correspondências entre os anos de 1949 e 1958, envolvendo o pleito desses indígenas pelo direito de posse de suas terras à 4a Inspetoria Regional e ao Conselho Diretor do SPI. Além de telegramas e ofícios, consultamos o Relatório de Viagem do antropólogo Hohenthal Jr. ${ }^{9}$, produzido no ano de 1952 para o órgão indigenista. Nele 0

\footnotetext{
${ }^{7}$ Resultado dos trabalhos de conclusão de curso na Licenciatura Intercultural (UFPE) e na Especialização em Educação Intercultural do Instituto Federal de Educação e Tecnologia do Sertão Pernambucano.

${ }^{8}$ Vivem na Serra do Umã, município de Carnaubeira da Penha. A TI foi demarcada na década de 1990 e, segundo dados da Fundação Nacional do Índio (Funai), encontra-se regularizada com 16.290 ha. Fonte: http://www.funai.gov.br/index.php/indios-no-brasil/terras-indigenas. Acesso em set.2019.

9 O norte-americano William Dalton Hohenthal Jr. da Universidade da Califórnia, em Berkeley, viajou pelo Sertão do São Francisco (1951-1952) com a finalidade de fazer um levantamento etnológico sobre os indígenas dessa região. Entre o material etnográfico produzido por essa pesquisa, estão o "Relatório de viagem aos índios da I.R.4" endereçado para José da Gama
}

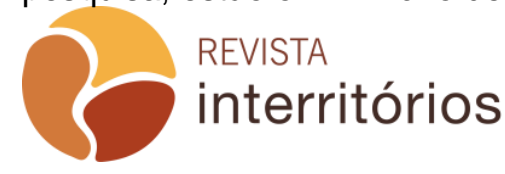


antropólogo faz referencia ao grupo como Pacarais. Enfatiza também as perseguições sofridas pelos índios, inclusive tendo-as presenciado e relato às minúcias.

Surgem na referida documentação no contexto da instalação do Posto Indígena Estácio Coimbra, na Serra Umã, efetivada em 1949. A criação do Posto tornou-se um advento importante não só para os Atikum, mas reverberou entre a população indígena do entorno, entre estes os Pacarais [Pankará]. Aos Atikum foi garantido o direito sobre 18.000 hectares na Serra Umã e outros benefícios, como o açude, escola, casa de farinha, entre outros (GRÜNEWALD, 1993). Nas entrevistas com os anciãos e anciãs, afirmaram que havia um entendimento de que a assistência tulelar do SPI abrangeria todas as famílias indígenas que tinham habitação e roça no território cultural mais amplo, dos descendentes dos Umãs; ou seja, o complexo de serras dessa localidade que engloba a Serra do Arapuá.

Outro fato que contribuiu para os Pankará desenvolverem a crença de que o Posto Indígena significava uma solução para os problemas que enfrentavam na Serra do Arapuá tem a ver com a participação destes no episódio que "deu origem à aldeia" na Serra Umã. Trata-se de uma narrativa viva da memória coletiva dos Atikum e Pankará, que se tornou um importante definidor de indianidade, sendo os "índios de verdade" aqueles que "deram presença" no Toré que atestou existir índio naquele território, para o SPI:

Joaquim Amanso[índio] sabia do nosso trabalho aqui e mandou buscar, nós fomos para Serra do Umã (...) Era Zé Brasileiro, Sampaio e Dr.Tubá, eram três que tinha [do SPI]. Entramos no terreiro e entramos dançando na batida do pé: pam, pam, pam. Pedro Dama, mais Manoel Bezerra, disseram: "ói, caboco é desse jeito aí, podem tirar a cela do animal". Eu sei que foram três dias; de noite teve o culto lá e aí fundaram Serra do Umã." (Pedro Limeira, pajé Pankará, citado por MENDONÇA, 2003, p.47).

Não há como negar que esse episódio representa um marco político no processo de afirmação identitária e territorial dos Pankará. São recorrentes as narrativas do evento carregadas de entusiasmo e jocosidade, principalmente entre os mais velhos, pois é comum nas rodas de conversa a lembrança desse dia e difícil encontrar alguém que não esteve presente no alto da Serra Umã para dançar o Toré ao SPI.

A partir de então, o conteúdo dos documentos da época versam sobre pedidos de reconhecimento oficial dos indígenas na Serra do Arapuá e Cacaria, denúncias de violências praticadas contra esses índios e a posição do

Malcher, Diretor do SPI, em 1952, e o artigo "As tribos indígenas do médio e baixo São Francisco", lançado em 1960 pela Revista do Museu Paulista.

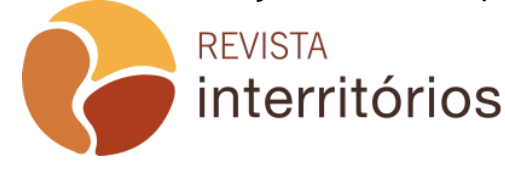


governo diante desses fatos. No conjunto da documentação ${ }^{10}$ destacamos 0 personagem Luiz Antonio dos Santos, conhecido por Luiz Limeira ${ }^{11}$, que aparece de forma recorrente no material examinado; ele é pai do pajé Pedro Limeira e avô paterno da cacique Dorinha.

A história do líder Luiz Limeira revela os primeiros enfrentamentos deste povo ao poder colonial/hegemônico no cenário da reivindicação territorial dos Pacarais em 1949. Encontramos um telegrama remetido por Luiz Limeira, dirigido ao chefe de Posto da Serra Umã, dizendo ter sido encaminhado pelo chefe de Posto de Rodelas (Tuxá), para que este assumisse as "providências" na assistência aos indígenas na Cacaria. No documento Luiz Limeira também pede ajuda por estar sendo perseguido pela polícia de Floresta: "eu quero que o Snr. faça tudo por mim para os homens conhecerem o que é serviço de proteção aos Índio que eles estão pensando que não tem valor e nem prestijo, sem mais do seu $\mathrm{Cr}^{\circ}$ e Obio ${ }^{\circ} t^{o}$ Índio. Luiz Antônio dos Santos." 12

O pleito dos Pankará não foi atendido pelo SPI. Com a extinção do órgão, a demanda foi arquivada. Intensifica-se um período hostil e de violência muito presente na memória dos mais velhos de hoje. São inúmeros os relatos sobre as proibições da prática do ritual, as "noites de fuga" para dançar o Toré escondido "dos brancos", a violência física e moral contra algumas lideranças. Entre as várias violências, há dois episódios que marcaram a memória dos Pankará: a proibição de acessar a água e o incêndio criminoso da casa de Luiz Limeira. Os filhos mais velhos de Luiz Limeira relataram o episódio em que os invasores da Terra Indígena os proibiram de ter acesso à água e seu pai viajou ao Recife em busca de solução junto ao SPI. A este respeito, comenta Hohenthal Jr. ${ }^{13}$ :

O índio Pacará que sofreu mais que todos os outros foi Luiz Antônio dos Santos e família. Este homem, com quem estive hospedado trabalha um terreno de extensão ignorada, talvez 20-30 hect. Ele tem que pagar $10 \%$ da safra a um tal José de 'Cis' (Assis?) da família dos Leite; essa família quer que João de 'Cis' jogue fora o índio Luiz Antônio, mas até minha visita este não havia agido. A família Leite já obrigou Luiz Antônio abandonar dois sítios com casas, bens, arvores frutíferas, e até

\footnotetext{
${ }^{10}$ A documentação produzida neste período consta no acervo do Museu do Índio, Coleção documental Inspetorias Regionais, projeto "A História Invisível da Resistência Indígena".

${ }^{11}$ Entre os Pankará há uma distinção entre nome de família e sobrenome. Sobrenome é a identificação nos registros oficiais e família remete aos grupos de parentesco que formam a organização social e perpetua a descendência histórica (Amanso, Limeira, Rosa, Caxiado, Miguel).

${ }^{12} \mathrm{MI} / \mathrm{SEDOC}$ - Inspetorias Regionais, IR 4 Nordeste. Microfile 152, fotograma 2. CARTA, Serra da Cacaria/Serra Umã, 28 nov. 1949.

${ }^{13} \mathrm{MI} / \mathrm{SEDOC}$ - Inspetorias Regionais, IR 4 Nordeste. Microfilme 379, fotogramas 814-817.

RELATÓRIO, Califórnia, 14 jul. 1952.
}

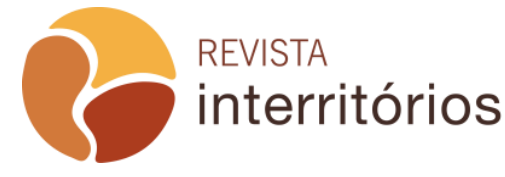


confiscarem a colheita. No ano passado (1951) a família Leite mandou a polícia de Floresta para jogar Luiz Antônio e família fora do sítio; ele não estava la no momento, e a policia (com a justificação não sei) derrubou a casa de taipa, deixando seus filhos menores e a esposa, que estava no sexto mês de gravidez, sem abrigo e sem comida, pois confiscaram essa e também 300 cuias de farinha de mandioca. Eu vi as ruínas da casa.

A partir da negativa do SPI e diante da interdição violenta do processo de territorialização do povo, ao final da década de 1950, os Pankará optaram por uma estratégia de resistência pela via interna, mantendo vivo circuitos rituais e de autoproteção por meio das redes de parentesco. São submetidos a condição de arrendatários, meeiros e viveram numa certa invisibilidade por cinco décadas. As reivindicações ao órgão indigenista oficial, neste período, e os enfrentamentos diretos aos invasores da Terra Indígena são interrompidos e a ocupação não indígena na Serra do Arapuá impõe-se na associação entre a concentração fundiária e o poder político dos não índios.

Depois deste período, os Pankará passam a ser conhecidos no cenário político contemporâneo no ano de 2003, durante o I Encontro dos Povos em Luta pelo Reconhecimento Territorial, promovido pelo Conselho Indigenista Missionário $(\text { Cimi })^{14}$. Compartilham com outros povos a seguinte identificação: "não somos nem emergentes, nem ressurgentes: somos povos resistentes". A expressão coletiva, que se tornou a marca do encontro, foi criada pelos povos na tentativa de organizar o discurso na lógica do movimento indígena, ao invés da simples apropriação das categorias utilizadas pelos antropólogos e indigenistas de "emergência étnica" e "ressurgência étnica". No espírito de afirmar o existir que os Pankará se apresentaram publicamente e sempre 0 fazem falando das lutas dos antepassados e do seu modo de viver no território tradicional.

No ano de 2009, a Fundação Nacional do Índio (FUNAl) instaurou processo administrativo pela regularização fundiária da Terra Indígena ${ }^{15}$ respondendo, tardiamente, a uma reivindicação das lideranças Pankará ao Estado brasileiro que surge na década de 1940.

Os conflitos enfrentados pelos Pankará na Serra do Arapuá desde então evidenciam a permanência do padrão de violência vivido anteriormente. Inclusive porque os opressores continuam os mesmos. Persiste um campo complexo de relações intersocietárias com os não índios que se impõe pela

\footnotetext{
${ }^{14}$ Ocorreu na cidade de Olinda/Pernambuco e, após o termino do encontro, a Fundação Nacional do Índio (Funai) divulgou uma lista de 36 povos intitulada "Povos Indígenas Oficialmente Reconhecidos pela Funai"; entre estes, os Pankará e os Pipipã em Pernambuco.

${ }^{15}$ A Terra Indígena Pankará está delimitada aguardando a Portaria Declaratória e demais procedimentos. C.f. www.funai.gov.br/index.php/indios-no-brasil/terras-indigenas. Acesso em: 20 set 2019.
}

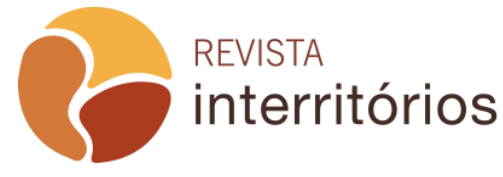


herança coronelista, operando com suas várias conexões de violência, exploração e dominação.

As famílias "tradicionais"16 do entorno, que foram beneficiadas pela Lei de Terras (1850) são as que possuem maior poder econômico e vantagem política; exercem total influência sobre os não índios que se estabeleceram na Serra ao longo do século $\mathrm{XX}$, como pequenos proprietários e/ou empregados em suas propriedades. Estes últimos estabeleceram relações de matrimônio com as mulheres indígenas, todavia mantiveram-se subservientes ao projeto colonizador na Serra e opõem-se à organização social Pankará. Atuam na atualidade produzindo muitas dissociações internas e dificuldades ao projeto societário mais emancipador.

Outro dado importante para caracterizar o contexto local é a influência dos indígenas nos rumos da política eleitoral de Carnaubeira da Penha. Conforme destaca a pesquisadora Lara Andrade (2010), o município é habitado majoritariamente pelos povos indígenas Atikum e Pankará que, juntos, somam aproximadamente 9.468 pessoas, ou seja, 80,35\% da população municipal e $96,61 \%$ da população rural. Carnaubeira da Penha está entre os dez municípios com menor Índice de Desenvolvimento Humano (IDH) de Pernambuco: 0,573 (PNUD, 2010) ${ }^{17}$.

Portanto, a tentativa de compreender o padrão de violência que subjaz a experiência vivida pelos indígenas implica em estabelecer uma vinculação com todas as dimensões que envolvem a sujeição dos Pankará. Analiso estas relações sociais fundadas na racialização dos índios a partir do conceito de Colonialidade do Poder (Quijano, 2005). Basicamente, a ideia de raça significa dizer, na visão eurocêntrica, que supostas diferenças de estrutura biológica impõem uma situação natural de inferioridade em interface ao outro. Mas, na definição de Quijano, do que se trata esse novo padrão de poder? "Uma construção mental que expressa a experiência básica da dominação colonial e que desde então permeia as dimensões mais importantes do poder mundial, incluindo sua racionalidade específica, o eurocentrismo" (QUIJANO, 2005, p. 227).

Observamos durante o trabalho de campo que os Pankará passam a operar um esforço coletivo e articulado para romper com a dominação estabelecendo alianças internas entre os "troncos velhos", para garantir a unidade política, e também na coalização de forças com algumas comunidades tradicionais do entorno, a exemplo das comunidades quilombolas, em particular a comunidade Tiririca dos Crioulos.

${ }^{16}$ O termo "família tradicional" é usado na região para indicar vínculos com a oligarquia agrária que se formou em séculos passados por meio da constituição das fazendas. Caracterizam-se pelo monopólio do poder político e econômico, patronagem e mandonismo.

17 Cf. Programa das Nações Unidas para o Desenvolvimento (PNUD), 2010. Disponível em: http://www.pnud.org.br/arquivos/ranking-idhm-2010.pdf. Acesso em: dez 2012.

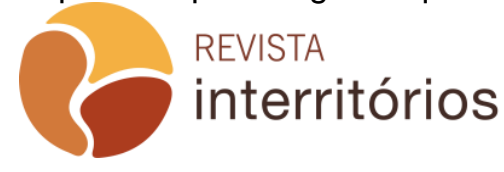


Nos anos de 2003 e 2004 foram intensas as reuniões nas comunidades, tendo como ponto de partida aquelas que mantinham o ritual e possuíam os terreiros de Toré. Segundo informaram os entrevistados, o objetivo era de retomar a história daqueles terreiros e a escolha da liderança local. Com um corpo de lideranças organizado, os Pankará se articulam com o movimento indígena e começam a integrar a Articulação dos Povos e Organizações Indígenas no Nordeste, Minas Gerais e Espírito Santo (APOINME) e a Comissão de Professores/as Indígenas em Pernambuco (COPIPE).

Essa articulação em rede trouxe para os Pankará importantes conquistas no campo dos direitos. Em 2004 conseguiram a estadualização de todas as escolas do território, além de duas equipes de saúde. Tais conquistas, porém, geraram grandes conflitos com a Prefeitura de Carnaubeira da Penha, o que se estende até os dias atuais, diante da recusa das lideranças tradicionais em manter o povo subserviente aos desmandos dos grupos políticos que colonizaram a região.

$\mathrm{Na}$ seção seguinte, apresentamos a etnografia da Retomada da Educação, caracterizada, inicialmente, como uma mobilização situacional e que veio a se transformar numa decisão coletiva e permanente para romper com 0 padrão de poder vigente e criar as condições de salvaguardar e garantir suas instituições.

\section{A Retomada da Educação}

Até o ano de 2004, as escolas situadas na Serra do Arapuá estavam sob a responsabilidade do município, com direção e quadro docente formado por professoras não indígenas. Havia 20 escolas e ofertavam até a primeira etapa do Ensino Fundamental. Com a entrada do povo Pankará na Copipe, decidiram reivindicar a estadualização de suas escolas como uma decisão política coadunada com os demais povos do estado de Pernambuco ${ }^{18}$.

A decisão da Copipe pela estadualização baseou-se na análise de que as escolas, sob responsabilidade do Poder Público municipal, estavam no controle das elites que oprimiram os povos ao longo dos tempos. Além disso, comumente os governos municipais ignoravam a Legislação Nacional vigente ${ }^{19}$ e ofertavam a educação escolar como "escolas rurais". As mudanças políticoadministrativas impingiram um processo que compreende até hoje uma intensa

\footnotetext{
${ }^{18}$ A Secretaria de Educação do Estado de Pernambuco incorporou todas as escolas indígenas à Rede Estadual através do Decreto n.. 24.628 de 12/08/2002. As escolas Pankará foram incorporadas no ano de 2004.

${ }^{19}$ Para maior informação sobre a legislação da Educação Escolar Indígena consultar: http://portal.mec.gov.br/seb/arquivos/pdf/vol4c.pdf. Acesso em: set 2019.
}

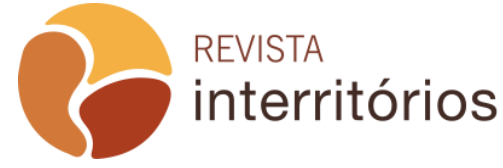


atuação política do movimento indígena nos rumos da política educacional em Pernambuco.

Segundo as narrativas indígenas, o prefeito da época, insatisfeito com a resolução dos Pankará em agir sem a sua autorização, buscou maneiras de criar obstáculos para a concretização da decisão dos índios. Conforme artigo escrito pelas professoras Pankará, uma série de conflitos passa a ocorrer, pois o povo decidiu exercer sua autonomia e enfrentar os antagonistas. No dia 13 de janeiro de 2004 acontece o primeiro ato do movimento conhecido como a Retomada da Educação:

Com a estadualização das escolas $^{20}$, o poder municipal de Carnaubeira da Penha se sente prejudicado, considerando que a estadualização das mesmas era uma perda para o município no sentido financeiro e de domínio da população. Então, passa a utilizar de estratégias para desarticular a organização do povo, não a reconhecendo e ainda afirmando não conhecer índios na Serra do Arapuá. Podemos dizer que a primeira retomada da educação escolar aconteceu em 13 de janeiro de 2004. Após saber que o prefeito de Carnaubeira da Penha estava se organizando para subir a Serra e desarticular a organização das escolas. Ele queria interferir no rumo da nossa educação escolar; as principais lideranças junto com os professores e a comunidade impediram a entrada do poder municipal através do Toré na cancela da Aldeia Brejinho. Esse foi o grande movimento que mostrou a autonomia do povo e o desejo que tínhamos de sermos respeitados. No início de 2004 todos se reuniram em busca de uma educação escolar diferenciada, que valorizasse a cultura e os saberes do povo e uma Saúde que atendesse as nossas necessidades, com mais autonomia, respeito e legitimação da identidade Pankará. O povo começa a participar dos encontros e se envolver na luta com outros povos indígenas de Pernambuco, o que fez a luta do povo Pankará se fortalecer. (SILVA; ROSA; SILVA, 2012, p.7).

O movimento de Retomada da Educação se corporifica a partir de uma sequência de atos coletivos desencadeados pelos indígenas e posteriormente assumidos pelos quilombolas da Tiririca dos Crioulos. Percebo que a escola é apropriada, nesse contexto, como uma oportunidade e também uma aposta política e epistêmica de ação contra as estruturas de opressão locais, pois a Retomada da Educação vai ganhando feições através de uma organização para a desobediência.

\footnotetext{
${ }^{20}$ A Resolução 03/99 do Conselho Nacional de Educação definiu que a oferta da educação escolar indígena é de responsabilidade da esfera estadual. Antes as escolas indígenas eram consideradas "escolas rurais" vinculadas a esfera municipal, obedecendo as normas gerais da educação brasileira.
}

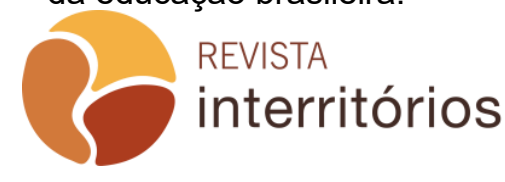


O fechamento da cancela do Brejinho com o Toré não foi uma ação impetuosa do grupo, ao contrário, demandou a utilização de uma sequência de procedimentos práticos utilizados nas retomadas: mobilização das aldeias para fazer a ocupação e garantir a infraestrutura; planejamento das estratégias em segredo; rituais com Toré, reuniões/negociações sistemáticas; articulação de outros povos e de instituições aliadas; denúncias aos órgãos competentes para assegurar o direito retomado.

Assim, na concepção Pankará, o movimento é considerado uma "retomada" porque se assemelha, na prática e nos efeitos, às retomadas de terra. Para sua concretização, os Pankará conseguiram mobilizar aldeias que estavam, até aquele instante, à margem das dinâmicas de reivindicação reiniciadas a partir de 2003. A rotina na retomada durou dias, reavivou os vínculos políticos e de solidariedade entre os grupos de parentesco por um objetivo comum: o direito de decidir sobre os rumos da vida comunitária. O que foi inicialmente uma reação ao autoritarismo do prefeito tornou-se um movimento que abarcou dimensões mais amplas.

Quando falam em Retomada da Educação, significa tomar posse das escolas já existentes que estavam sob a gestão do município; a criação de novas escolas; construir um Projeto Político Pedagógico (PPP) ${ }^{21}$ a partir da comunidade. No que se refere à criação de escolas, relatam que agiram por duas vias: a primeira foi o levantamento de recursos próprios para construção colocando-as em pleno funcionamento para, em seguida, encaminhar o reconhecimento à Secretaria Estadual de Educação (Seduc). A segunda foi exigir da Seduc as construções por meio do planejamento da Copipe no Conselho Estadual de Educação Escolar Indígena. Na primeira situação, todos/as os/as servidores/a disponibilizaram seu trabalho voluntariamente até serem contratados. Há casos em que a escola funcionou quase um ano sustentada exclusivamente pela comunidade. Em relação ao PPP, será melhor abordado na próxima seção.

Colocadas as questões mais gerais, o que segue, a partir de agora, é uma descrição etnográfica dos principais episódios que caracterizam a "Retomada da Educação"22 como atos de desobediência e de resistência cotidiana contra a Colonialidade do Poder.

\footnotetext{
${ }^{21}$ É corriqueiro o uso do termo ora como Retomada da Educação, ora como Retomada da Educação Escolar. Mesmo sabedoras de que 'educação' e 'escola' são categorias distintas, pois, a maior parte são pedagogas e licenciadas, estas distinções perdem o efeito diante do que elas querem anunciar: retomar saberes, valores, éticas e práticas que co-existiram no processo colonial ao tempo em constroem uma nova pedagogia escolar a partir do intento de descolonizar a escola e as relações de poder na Serra do Arapuá. Para efeito deste artigo, vamos utilizar os dois termos considerando os sentidos atribuídos pelo povo.

${ }^{22}$ Esta descrição foi uma elaborada em conjunto com as professoras que coordenam a Organização Interna da Educação Escolar Indígena Pankará (OIEEIP). Utilizamos a metodologia da cartografia social para mapearmos todas as ações coletivas desencadeadas desde 2003. O mapa produzido faz parte da minha tese. Agradeço a todas em nome de Luciete

\begin{tabular}{l|l} 
REVISTA & Interritórios \\
Interritórios | Revista de Educação \\
Universidade Federal de Pernambuco, \\
Caruaru, BRASIL | V.5 N.9 [2019]
\end{tabular}
}


A Serra do Arapuá tem 900 metros de altura e a formação das comunidades indígenas segue a geopolítica baseada nas relações de parentesco. São 52 aldeias organizadas em seis núcleos correspondentes a toda área reivindicada como terra tradicional: Pé da Serra do Catolé, Agreste, Chapada, Lagoa, Pé da Serra da Cacaria, Pé da Serra Grande e Comunidade Quilombo Tiririca ${ }^{23}$ (PPP 2007, p.16). Assim como as famílias e os terreiros de Toré alastram-se por todas as regiões da Serra, a escola foi sendo integrada seguindo a mesma lógica espacial, política e religiosa.

No período compreendido entre 2004 e 2013, os Pankará retomaram escolas situadas nos lugares de interesse do povo, tais como todas as áreas reivindicadas como Terra Indígena; as aldeias com maior incidência dos não índios; as aldeias do Sertão que passaram a integrar a organização social a partir de 2010, com destaque para o quilombo-indígena Tiririca dos Crioulos.

Respaldados pela legislação em vigor à época ${ }^{24}$, decidiram que a oferta da educação escolar passaria a ser gerida politicamente pela organização social do povo. Retiraram todos/as os/as professores/as não índios/as, percorrem todas as aldeias para cada comunidade indicar um/a professor/a e desencadeiam a pesquisa e sistematização do Projeto Político Pedagógico. Atualmente são 26 Unidades Escolares, sendo 23 escolas e três extensões (anexos) localizadas em 26 aldeias. Atendem a aproximadamente 1.300 estudantes com oferta da educação infantil ao ensino médio (PPP 2007, p.11).

Como dito, em 2004 as escolas foram estadualizadas e, em 2006, a Secretaria Estadual de Educação iniciou um processo de melhoria na infraestrutura de todas as escolas indígenas que passaram a integrar sua rede. Mas, na Serra do Arapuá, os índios enfrentaram a reação dos proprietários de terra e, uma situação em particular, exemplifica a colonialidade vigente na Serra.

O fato ocorreu na aldeia Pitombeira. Toda a área espacial dessa aldeia é propriedade de uma família da elite agrária local. Nela localizava-se uma escola de taipa, com uma sala de aula. A Organização Interna da Educação Escolar Indígena Pankará (OIEEIP) propôs à Seduc a construção de uma escola de alvenaria, mas o proprietário da terra proibiu. Logo em seguida, as lideranças são informadas que essa escola foi extinta por ato administrativo da Secretaria Estadual de Educação ${ }^{25}$. Os Pankará mantiveram a turma de alunos

Lopes, Noêmia Lopes, Fernanda Pereira e Ana Maria de Barros, coordenadoras da OIEEIP à época da pesquisa. A contribuição e parceria delas foi e tem sido imprescindível, inclusive para a atualização de dados que trago neste artigo.

${ }^{23}$ Do ponto de vista jurídico, o quilombo Tiririca está sendo regularizado na modalidade de Terra de Comunidade Remanescente de Quilombo. Foi uma opção da comunidade apoiada pelos Pankará.

${ }^{24}$ Resolução 003/99 do Conselho Nacional de Educação.

${ }^{25}$ Isto ocorreu à revelia do povo Pankará por ato da gestora da Gerencia Regional da Seduc, cuja sede está Floresta. Ela pertence a mesma família do proprietário que impediu as

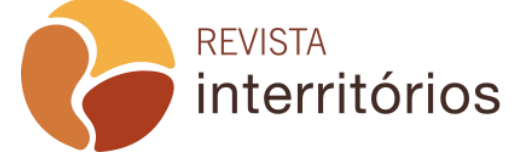


dessa escola em atividade na casa de uma família da aldeia, e desencadearam o processo de luta para tornar a Portaria de Extinção sem efeito. Essa resistência durou todo o ano de 2007 até conseguirem reverter a situação com o apoio institucional do Centro de Cultura Luiz Freire ${ }^{26}$ e da Copipe.

A desobediência Pankará à ordem de extinguir a escola repercutiu na ação corporativa da família que se dizia dona da terra contra os índios. A seguinte ordem esquemática de ataques se sucedeu: primeiro o dono da terra proíbe a construção da escola; em seguida, sua parenta, diretora da Gerencia Regional de Educação (GRE) de Floresta, encaminha à Seduc o pedido de extinção, no que é atendida; como consequência, os indígenas reagem e o prefeito de Carnaubeira da Penha em exercício (também da mesma parentela) organiza um grupo de homens armados para coagir a cacique Dorinha a entregar o cacicado para pessoas de sua base eleitoral. Sobre isso, analisam os Pankará:

No ano de 2007, o prefeito em exercício articula um pequeno grupo para tirar a cacique Dorinha, utilizando de ameaças com o intuito de ter de volta o poder de domínio da população. Porém, não sendo da vontade do povo, ele parte para outra estratégia: a de corromper as lideranças ligadas ao movimento e induzir a disputa de poder entre os próprios índios, com o intuito de dividir o povo. O mesmo passaria a se chamar Pankará 1 e 2. (SILVA; ROSA; SILVA, 2012, p. 8).

No início do ano de 2008, o prefeito volta as investidas contra a Retomada da Educação e, articulado com ocupantes não indígenas, interditou duas escolas nas aldeias Jardim e Enjeitado, mesmo elas sendo estaduais, impedindo o acesso de alunos/as e professores/as. Tal interdição ocorreu de forma violenta, utilizando-se de mecanismos de coerção, conforme vários relatos de lideranças e membros da comunidade, que apesar de pedirem para não serem identificados, por entrevista, fizeram o relato:

O dono lá da terra que fica a escola Quintino de Menezes botou homem armado na frente da escola. A gente não pode entrar nem para tirar o material didático. Toda a comunidade

melhorias na escola e usou do seu posto para encaminhar o pedido de extinção. Havia uma concepção de que as escolas eram benesses dos fazendeiros aos moradores pobres da serra, na maioria, seus empregados, e no caso, os índios. De modo que bastasse uma pequena sala de taipa, pois a alvenaria simbolizaria apropriação indevida de área em sua propriedade.

${ }^{26}$ Centro de Cultura Luiz Freire (CCLF) é uma organização não governamental com sede na cidade de Olinda-PE, fundada em 1972. Desenvolveu atividades sistemáticas com os povos indígenas em Pernambuco entre os anos de 1997 a 2010, e tem uma importante contribuição no surgimento da Comissão de Professores/as Indígenas de Pernambuco (Copipe) e na criação e efetivação da política de educação escolar indígena no Estado.

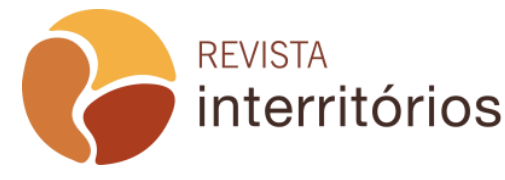


ficou lá nesse estado de terror, com aqueles homens lá armados (professoras Pankará, 2010).

Isso foi por muitos dias. Dizendo que era para ninguém entrar na escola, mas era também para vigiar a comunidade, intimidar a gente, porque conseguimos reabrir a escola da Pitombeira. E conseguimos reabrir essas também. O prefeito fecha, a gente abre. Ele tira o direito das crianças, a comunidade garante. Todas as turmas das duas escolas colocamos para funcionar em casa de família. Mas, na Quintino de Menezes, era muito ruim, porque as crianças viam aqueles homens armados na frente da escola delas, na frente da casa delas. E, nós professoras, que continuamos dando aula, nos sentimos muito ameaçadas. Muito triste lembrar disso tudo, muito triste as crianças viverem essa violência (professoras Pankará, 2010).

Várias medidas foram tomadas pelas lideranças junto às organizações de apoio aos indígenas, Centro de Cultura Luiz Freire (CCLF) e Conselho Indigenista Missionário (Cimi) ${ }^{27}$. A gravidade do conflito envolvendo a prefeitura e os indígenas impeliu estas organizações, que atuam diretamente na defesa dos Direitos Humanos, a darem visibilidade nacional e internacional aos fatos, a exemplo da Relatoria Nacional para os Direitos Humanos à Educação/Plataforma Brasileira de Direitos Humanos, Econômicos, Sociais, Culturais e Ambientais (Dhesca Brasil), que realizou missão de monitoramento em Pernambuco, no mês de outubro de 2008, para tratar da questão prisional e da questão Pankará28.

A medida que retomavam escolas, a tensão com fazendeiros, não índios aliados a eles e o Poder Público municipal foi se intensificando. Assim os Pankará buscaram alternativas e criaram laboriosas estratégias de fortalecimento interno em parceria com o movimento indígena e com as organizações indigenistas. No mês de abril de 2007, os Pankará acolheram no território um encontro de povos indígenas do Nordeste, intitulado "Terra Toré: territorialidade, religião e identidade"29. O encontro foi todo organizado pela

\footnotetext{
${ }^{27}$ Foram denúncias encaminhadas pela assessoria jurídica do CCLF para o Ministério Público Federal - Procuradoria da República no Município de Salgueiro/PE.

${ }^{28} \mathrm{Na}$ ocasião, realizou várias interlocuções com órgãos de Estado, além de ter feito uma ação urgente, encaminhando um informe para várias organizações nacionais e internacionais, além de mídia sobre o caso Pankará. Foi dada reintegração de posse à Secretaria Estadual de Educação, mas os/as índios/as sentindo-se inseguros, optaram por construir as escolas em aldeias vizinhas. As escolas foram construídas com recursos próprios da organização Pankará que se cotizou entre as aldeias e os/as funcionários/as da saúde e educação.

${ }^{29}$ Segundo informa o documento final do encontro, estiveram presentes povos indígenas de cinco estados no Nordeste do Brasil e o encontro teve como objetivo "refletir sobre a importância do território para nossa sobrevivência física, cultural e espiritual, tratando sobre as questões ligadas à nossa espiritualidade na relação com a terra como nosso Solo Sagrado, onde vivem os Encantos de Luz e a nossa ciência" (Cf. documento na íntegra no site: http://www.cimi.org.br/site/pt-br/?system=news\&action=read\&id=2476\#. Acesso em janeiro de 2013).

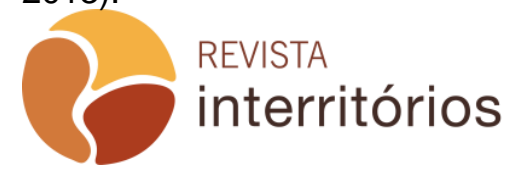


Organização da Educação (OIEEIP) e, desde então, variados encontros do movimento indígena são realizados na Serra do Arapuá.

Nos três anos seguintes, os Pankará passam a envolver-se diretamente com o processo de regularização territorial favorecendo a rearticulação interétnica com o quilombo da Tiririca dos Crioulos. Desde a segunda metade do século $X X$, até aquele momento, tais relações estavam circunscritas às redes de sociabilidade e de ritual. Com a instauração do Grupo Técnico da Funai, estabelecem vínculos mais orgânicos e os membros da Tiririca passam a compor o GT junto com as lideranças Pankará. Estabelecida a aliança, mais uma vez a prefeitura atua em retaliação aos Pankará e fecha a escola no quilombo Tiririca, mantida pela gestão municipal.

É reaberta pelos Pankará e Tiririqueiros em 2011 e na sequência criada sob a categoria Escola Indígena formalizada pelo governo estadual,

No ano de 2010, o território Pankará começou a ser identificado pela Funai e isso aumentou os conflitos locais com os brancos e políticos da região, então houve a necessidade de mudar a educação escolar da Tiririca. A gestão da nossa escola pelo município que perseguia os Pankará não estava agradando o povo da Tiririca. O prefeito de Carnaubeira da Penha passou a nos perseguir também e, em retaliação pelo fato da nossa comunidade ser unida com Pankará, fechou a escola. Então, junto com os Pankará, conseguimos que o Incra começasse os estudos de identificação do território quilombola e reabrimos a escola por meio da estadualização como escola indígena Pankará. (SANTOS SÁ, 2016, p.10).

Como é possível perceber até aqui, as lutas pela escola simbolizam uma resistência cotidiana contra a colonialidade que opera sobre a população da Serra do Arapuá. Como explica Quijano (2005), a dupla poder público/poder privado é um caminho que se estabeleceu sob a égide da Colonialidade do Poder impondo a inferioridade racial aos colonizados, reproduzindo o sistema de exploração e dominação da raça dita "superior" através do trabalho e da ocupação dos postos de mando do Legislativo e do Executivo desde o Brasil Colônia.

Os confrontos envolvendo a questão da educação escolar não cessaram. Com a estadualização, os avanços da política pública foram significativos. Contudo produziram imensos problemas. Como analisei em outro trabalho (MENDONÇA, 2016), a política de educação escolar sob a gestão do governo estadual passou a movimentar várias categorias de empregos: motoristas, secretárias, merendeiras, auxiliares de serviços gerais, porteiros, professor/a e professor/a de arte. A indicação para essas funções/empregos ficou sob a corresponsabilidade das organizações internas de educação, lideradas pela Copipe. Passaram a gerir também recursos provenientes dos

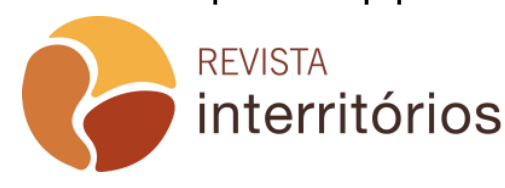


fundos Nacional e Estadual da Educação para a manutenção da estrutura física, execução dos projetos político-pedagógicos e administração da burocracia.

São conquistas da Copipe e respaldam o protagonismo indígena na incidência de políticas públicas. Todavia, o manuseio direto de tantos recursos colocou em evidência as contradições que estavam submersas no conjunto de interesses na Serra do Arapuá. A Terra Indígena está na primeira fase do processo de regularização: a delimitação. Os ocupantes não indígenas permanecem e atuam de forma constante na disputa com a organização Pankará. Nas alianças com indígenas descontentes com as lideranças tradicionais, em muitos casos tendo como motivo as vagas de emprego, os não indígenas concorrem pelo controle da política de educação demonstrando como o poder sobre o território passa pela governança das escolas.

O projeto de educação escolar na Serra do Arapuá segue enfrentando as dissidências internas. Os últimos conflitos, deflagrados com as eleições municipais de 2016, ganham contornos mais complexos por conta das características do processo de territorialização marcado por casamentos interétnicos. Alguns destes casos são de famílias que permanecem vinculadas, ou se vinculam circunstancialmente, a interesses contrários aos direitos coletivos dos Pankará. De um modo geral, as relações antagônicas caracterizam-se por tentativas de desestabilizar a organização social indígena.

Em conversa com as lideranças a respeito deste estado de tensão permanente contra a organização social, elas me explicaram que seus antepassados precisaram fugir muito dos brancos. Na fala de Pedro Limeira: "iam fugindo de um canto a outro e iam deixando marcas para a gente saber que essa terra aqui é dos índios. Por isso que a gente não sai daqui, nem empresta, nem vende (risos), é nossa herança, dos nossos antepassados". Pude compreender, apoiada em Frantz Fanon (2010), que não se pode desorganizar uma sociedade semeada de interdições sem derrubar todos os obstáculos pelo caminho. "O colonizado que decide realizar esse programa, que decide fazer-se o seu motor, está preparado, desde sempre, para a violência" (FANON, 2010, p. 53).

O movimento da Retomada assinala aquilo que o povo considera mais importante para demarcar uma posição política concreta, o (re) estabelecimento das fronteiras étnicas do povo. Ao mesmo tempo que avançam na construção da autonomia, pelo poder focado na comunidade, investem na construção do Projeto Político Pedagógico. O PPP vai sendo formulado com a orientação dos Encantados de Luz e dos pajés suscitando novos questionamentos sobre a concepção e objetivos da escola Pankará. 
"Retomada da Educação Escolar": um estudo sobre

Projeto Político-Pedagógico: reafirmando e construindo saberes decoloniais

A sucessão de enfrentamentos políticos vivido pelos Pankará e o quilombo Tiririca tem caminhado junto com o enfrentamento epistêmico. Inspirada em Walter Mignolo (2008), é factível afirmar que a Retomada da Educação veio a ser também um movimento de "desobediência epistêmica" por sua ousadia na criação de uma concepção de escola muito particular:

Para nós Povo Pankará é na tradição onde tudo começa. Com nossos pajés e anciãos, pois entendemos que eles são nossas raízes, que fortalecem a nossa fé e nos dão força para levar adiante as tradições. Desde os antepassados, até os dias atuais, vêm-se mantendo as crenças, como: pajelanças, benzedeiras, reinados (mestre Alves, Mané Maior, mestre Dondozinha, mestre Juazeiro, mestre Juana), terreiros (Dona Caiporinha, Caboclo Velho, mestre Roque, Zé Pilintra) e principalmente o nosso Toré. Nele buscamos a força dos encantados para lutarmos [...] $E$ os Encantos de Luz é quem nos alumeia. E os Encantos de Luz é quem nos alumeia. $A$ Jurema do caboclo é doce que só mel. Mas quem não sabe beber ela amarga que só fel. (PPP, 2007, p. 6. Grifo Meu).

A educação do quilombo Tiririca é compreendida como respeito aos anciãos, à ciência dos mais velhos, à história do povo da comunidade e a luta por políticas sociais adequadas e que melhorem as condições de vida e de autonomia dos povos (SANTOS SÁ, 2016, p.10).

Tradição é uma noção subjacente a todo o PPP, todavia ela não se refere à ideia de passado, mas está diretamente relacionada aos saberes e conhecimentos situados historicamente ${ }^{30}$. Ao longo dos anos em que convivo com estes povos, o termo tradição é recorrente nas falas de toda a comunidade como um enlace daquilo que tem sido aprendido da história de resistência dos mais velhos, da ciência do Toré e da racionalidade no presente. Uma racionalidade que passou a existir, intencionalmente, na crítica à sociedade capitalista e ao eurocentrismo, interpretado como modelo e como forma de conhecimento da modernidade/colonialidade, que se pretende hegemônico desde o século XVII (ESCOBAR, 2007).

\footnotetext{
${ }^{30}$ Alfredo Wagner traz uma definição pertinente a este estudo sobre o conceito de tradição. Ele argumenta que "a noção de 'tradicional' não se reduz à história, nem tão pouco a laços primordiais que amparam unidades afetivas, e incorpora as identidades coletivas redefinidas situacionalmente numa mobilização continuada [...]. O critério político-organizativo sobressai combinado com uma 'política de identidades', da qual lançam mão os agentes sociais objetivados em movimento para fazer frente aos seus antagonistas e aos aparatos de estado" (ALMEIDA, 2008, p. 30).
}

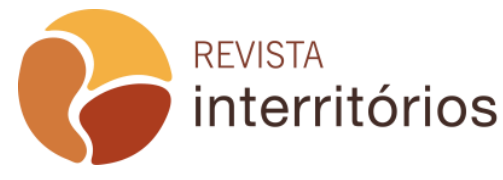


Observo que professoras e lideranças Pankará e da Tiririca têm como propósito superar os efeitos da colonialidade recorrendo à elaboração de uma pedagogia decolonial (WALSH, 2009). A decolonialidade como

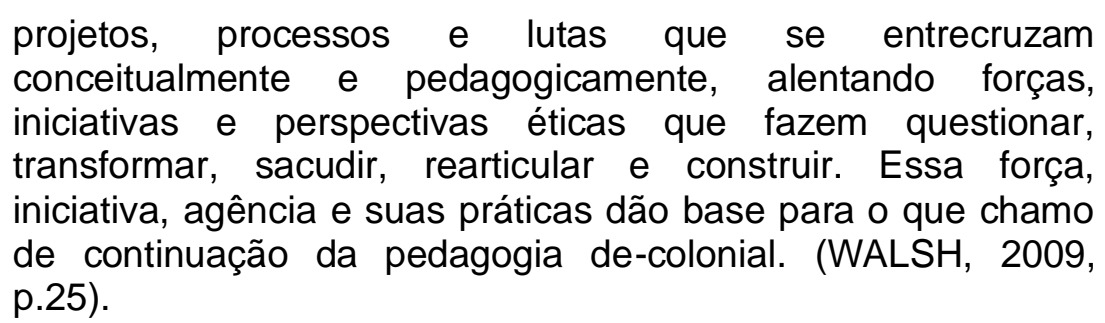

De forma criativa, as professoras imprimem à noção de escola este sentido de agência coletiva que pode ser acessado na ideia de projeto, se considerarmos que "os grupos não têm agência em sentido psicológico (como os indivíduos), mas os grupos certamente têm tanto "projetos" como "poder" (ORTNER, 2007, p.74). Por isso o PPP é para orientar a educação escolar do povo e não das unidades escolares. Há um único PPP para todo o território e não há direção nas escolas. A gestão é feita pela organização social, conforme demonstraremos adiante.

Como a escola não se reduz ao estabelecimento onde se ensina (com todo seu aparato de pessoal e administrativo-financeiro), no contexto intersocietário na Serra do Arapuá, enredado em relações de poder desiguais, ela é o projeto para dar conta do agenciamento epistêmico.

A necessidade de continuar sendo povo tem gerado essas novas práticas educativas, embasadas na historicidade e no desejo de retomar valores sociais e éticos que estavam subsumidos na resistência. A formulação do PPP consolida o movimento de Retomada da Educação, afinal, como afirma Meliá: "a construção da alteridade não só tem objetivos específicos numa ou noutra sociedade, mas também métodos próprios" (Meliá, 1999, p. 15).

Para o processo de sistematização do documento, a OIEEIP contou com a parceria institucional do Centro de Cultura Luiz Freire e amplo envolvimento das lideranças e comunidades, especialmente os mais velhos. Ademais, buscaram estar em consonância com a orientação do Movimento Indígena de Educação em Pernambuco. Nessa inter-relação estabelecem cinco eixos norteadores da educação escolar, os quais estão contidos no PPP dos demais povos representados pela Copipe: território, identidade, organização, história e interculturalidade ${ }^{31}$.

\footnotetext{
${ }^{31}$ Os cinco eixos da educação escolar indígena em Pernambuco foram criados durante o I Seminário de Formação para o Projeto Político Pedagógico, no ano 2000, em Recife. Promovido pelo Centro de Cultura Luiz Freire e pela Comissão de Professores Indígenas em Pernambuco (Copipe) teve como objetivos a formação dos/das professores/as indígenas e desencadear o processo de pesquisa e sistematização em cada povo. Os povos presentes
}

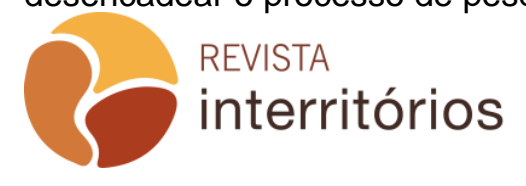


O Território é conceituado como "sagrado" e local de "esperança" na construção do projeto societário. A Identidade está diretamente vinculada ao território e à luta "pela conquista da mãe terra", afastando-se de um viés puramente ontológico. Também é compreendida em sua dinamicidade, posto que é "reelaborada sempre". O elemento da Organização vincula-se à perspectiva da "autonomia plena", organização e autonomia é uma dupla importante nas dinâmicas insurgentes Pankará e Tiririca. A história está centrada na historicidade do povo, no exemplo de vida dos antepassados e na valorização do passado de sofrimento e resistência como ensinamento para o presente: "seus sofrimentos não os devemos esquecer" e a "resistência deve servir como espelho nas lutas atuais". A Interculturalidade é a chave que liga 0 povo à sociedade envolvente e demais povos indígenas, considerando as diversas formas de "viver, pensar e conviver".

As formações continuadas para as professoras são asseguradas pelo próprio movimento indígena e possuem objetivos diversos:

A formação dos/as professores/as se realiza em vários espaços: em nossas comunidades, juntamente com os pais das crianças e jovens; com os anciãos, pajés, cacique, lideranças e no estudo e prática dos eixos que norteiam a nossa educação escolar [...]. Por isso nossos/as professores/as participam de todos os momentos da vida da comunidade, principalmente das discussões sobre a retomada do território. Assim como dos rituais, dos encontros entre os povos, das experiências entre as comunidades e aldeias. Valorizamos tudo que aprendemos na vida da comunidade e nas lutas que a partir dela acontece. Então, falamos de uma formação continuada, que se fortalece ainda mais nos encontrões da Copipe, do CCLF, do Cimi, nas nossas reuniões pedagógicas e nas feiras culturais que realizamos anualmente. Dessa forma nossa formação é contínua e os espaços onde ela se realiza são múltiplos. (OIEEIP, 2010, p. 22).

Há um aspecto importante para o povo, que é a articulação com o Movimento Indígena e organizações indigenistas para colaborar na politização dos/as professores/as. Uma politização que se dá participando dos espaços sociais e políticos na comunidade e no movimento indígena. Participam também das formações ofertadas pela Secretaria Estadual de Educação e instituições de ensino superior. Outro aspecto que merece destaque no projeto de escola é a política curricular. Os conteúdos são pensados como prática

foram: Xukuru, Kapinawá, Kambiwá, Pankararu, Atikum, Truká e colaboração do professor Gecinaldo do povo Sateré-Mawé (AM). Os demais povos, à medida que foram deflagrando seus processos de elaboração do PPP, aderiram a esta proposta de organização a partir dos eixos formulados no Seminário. No caso do povo Fulni-ô, falantes do Yaathê, acrescentaram o eixo da língua materna.

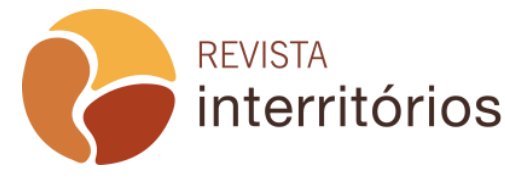


sociopolítica, o que me parece relevante e estratégico para a construção do currículo decolonial proposto pela OIEEIP. Os saberes e conhecimentos selecionados são abrangentes, as professoras levam a cabo o intento de abarcar todas as áreas da vida do povo através dos saberes ambientais, espirituais, econômicos, produtivos. Para a análise aqui proposta seleciono aqueles diretamente relacionados à história e à organização por serem, do meu ponto de vista, balizadores da Retomada da Educação: i) o processo educativo de valorizar a história e os saberes dos mais velhos; ii) o processo educativo de conhecer e comprometer-se com a organização social do povo.

Sobre o processo educativo focado na valorização da história e dos saberes dos mais velhos, tem sido o ponto de partida para descolonizar 0 currículo. Implica na realização de pesquisas sistemáticas aliada ao desenvolvimento de uma metodologia própria de publicação de material didático. Cada pesquisa resulta em um livro feito de maneira artesanal. A produção de conhecimento de autoria das professoras fez sobressair um tipo de protagonismo das mulheres indígenas e quilombolas. Elas pesquisam, escrevem, produzem os livros e difundem todo o conhecimento oral do povo.

A prática da pesquisa das professoras tem proporcionado às mulheres indígenas uma autonomia intelectual e feito difundir uma ampla produção de conhecimento sobre a resistência indígena no Nordeste a partir do ponto de vista das mulheres (MENDONÇA, 2016).

\begin{abstract}
Nessa reconstrução do ensino de história nas escolas Pankará, este não mais se resume apenas a datas comemorativas, fatos do passado, grandes heróis e nem valoriza apenas o presente. $O$ ensino estabelece relações entre o passado e presente, ajudando os guerreiros Pankará a refletir o quanto foram perseguidos, humilhados e acima de tudo resistentes. Nesse contexto, o ensino de história passa a valorizar os relatos orais dos mais velhos, o modo de ser e viver Pankará e as relações sociais, culturais e históricas, para melhor compreender a vida do seu povo e de outros povos em diferentes tempos e espaços com toda sua diversidade cultural (PEREIRA; PEREIRA, 2012, p. 4).
\end{abstract}

Assumem que conhecer a história do povo é condição essencial para dar continuidade à identidade coletiva. O empreendimento colonial, na América, teve início com três armas: a cruz, a espada e a escola (MELIÁ, 1979). A instituição escolar teve a missão de instituir e perpetuar a ordem social vigente e o ideal de "pessoa humana", segundo a visão de mundo do colonizador. A escola Pankará assume a responsabilidade de reverter essa tradição ocidental: 
As professoras, com o apoio dos anciãos, pajés, cacique e lideranças passam a escrever e a dar uma nova versão ao ensino de história. As escolas que até então eram um espaço de colonização para com o povo, hoje passa a ser um espaço de autonomia e principalmente um lugar onde se dá o direito de fazer o processo de descolonização dos saberes, até então repassados pelos não índios nas escolas através dos registros escritos nos livros didáticos e outros documentos (PEREIRA; PEREIRA, 2012, pp. 5-6).

$\mathrm{Na}$ pesquisa da história oral emergem vários conteúdos ocultados pela sujeição a que estavam submetidos no século passado. A escrita dessas mulheres professoras trouxe para o âmbito do público um relevante acervo da memória histórica do grupo. Os conteúdos versam sobre os mitos, a cultura, a ciência, as violências sofridas em todas as suas dimensões ao lado dos atos de resistência. Vejamos, para exemplificar, o texto da professora Alecksandra do quilombo-indígena:

O povo da Tiririca sofreu muitos preconceitos por ser negros, e eram tratados como animais, pois não tinha direito a nada que gente pode ter. Eram tratados com muito desrespeito pelos brancos e, por isso, continuamos lutando para combater com essa forma de racismo contra nosso povo. A educação escolar na Tiririca tem sido nossa maior aliada neste combate, e nossa luta continuará até que nosso território esteja livre do racismo e dos racistas. (SANTOS SÁ, 2016, p.11)

Acompanhando cada episódio histórico, as personagens. Vários homens e mulheres que participaram da resistência, no início do século XX, estão sendo (re)conhecidos, e isso tem provocado várias mudanças na organização social e de parentesco, fazendo o povo rever a sua própria história e concepções. Pode-se citar como exemplo a "descoberta" da participação dos quilombolas da Tiririca no episódio do Toré na Serra Umã para o SPI, em 1949, citado na primeira sessão deste artigo. Essa informação trouxe para indígenas e quilombolas a certeza de uma alteridade que vai sendo construída na história:

O povo Tiririca e os Pankará da Serra do Arapuá trocam muito conhecimentos, e nestas trocas o quilombo indígena Tiririca se auto-afirma como indígena também. Pois a partir do momento que constrói sua identidade na luta coletiva, juntamente com seus ancestrais, que são negros e indígenas, se forma uma organização política, social e religiosa que contém essas ancestralidades. É uma identidade de ambas as partes, pois, desde o início da Tiririca, o primeiro habitante era negro e casou com uma índia Pankará da aldeia Oiti e essa história continuou a se repetir. Manoel Miguel que era índio da Serra do 
Arapuá também casou com uma negra da Tiririca. Essa história se repete até os dias de hoje, os negros e negras da Tiririca sempre se casam com os índios e índias da Serra do Arapuá. Negros-índios, negras- índias. (SANTOS SÁ, 2016, p.3).

O texto acima nos aproxima dessa historicidade vivenciada na vida social e pluricultural na Serra do Arapuá. Na inter-relação com a história, indígenas e quilombolas assumem como conteúdo de sua pedagogia a valorização dos modos específicos de organização social.

Introduzo agora o processo educativo de "conhecer e comprometer-se com a organização social do povo". Antes, porém, cabe uma nota breve sobre a questão da organização social em análise. Tratar deste tema, na antropologia, implica analisar dimensões empíricas e teóricas amplas, que articulam categorias como autoridade, poder, conflito, parentesco. Entretanto, meu interesse analítico recai sobre a importância político-pedagógica que as professoras the atribuem porque sugere, a meu ver, que educar na e para a organização social, política e religiosa é uma agenda para alcançar a regularização e a autonomia no território.

A historicidade Pankará está circunscrita no contexto das lutas indígenas no Nordeste, dos processos de territorialização, tal como definido por Oliveira (1999) ${ }^{32}$. O Toré é um elemento ritual e sagrado que articula o povo historicamente. Nesse sentido, a organização social na atualidade é resultante de uma consciência refletida do povo em relação ao poder que o sagrado exerce historicamente nessa sociedade.

No período anterior à insurgência deflagrada, em 2003, mesmo sem a constituição de uma organização formal, havia lideranças e uma dinâmica organizativa instituída através do sagrado (MENDONÇA, 2003). Andrade (2010), para analisar o papel da organização social diante dos conflitos com o Poder Público municipal, conclui que a capacidade do povo Pankará de superar os constantes atentados à sua autonomia reside nos efeitos de poder que o sagrado desempenha para a mobilização política.

Em vários textos e documentos produzidos pelos Pankará, apresentam a organização associada ao religioso, "nossa organização social tem por base o Toré. Os mais velhos estão ligados à tradição, são eles que guardam a sabedoria da ciência Pankará" (LOPES; MARCOLINO; PEREIRA, 2011, p. 5). A antropologia vem, há muito tempo, afirmando que o sagrado compõe uma das dimensões do campo político; "a religião pode ser um instrumento do poder, uma garantia da sua legitimidade, um dos meios utilizados no quadro

\footnotetext{
${ }^{32}$ Para João Pacheco de Oliveira territorialização é um processo de reorganização social que implica: i) a criação de uma nova unidade sociocultural mediante o estabelecimento de uma identidade étnica diferenciadora; ii) a constituição de mecanismos políticos especializados; iii) a redefinição do controle social sobre os recursos ambientais; iv) a reelaboração da cultura e da relação com o passado. (OLIVEIRA, 1999, p.20).

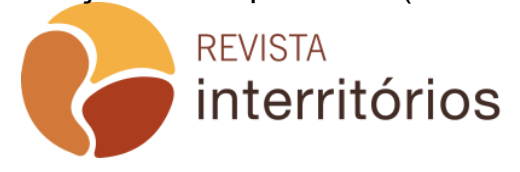


das competições políticas" (BALANDIER, 1987, p. 121). Sob a ótica da antropologia política, a ação pedagógica dos Pankará, voltada para a formação dentro da organização social, deve ser compreendida "não apenas sob o aspecto dos princípios que regem sua organização, mas também em função das práticas, das estratégias e das manipulações que elas provocam". (BALANDIER, 1987, p. 14).

Os agentes sociais identificados como responsáveis pelas ações educativas são os pajés, cacique, lideranças, anciãos e comunidade. Afirmam que a educação é comunitária e as professoras ocupam um lugar importante e estratégico, mas não são as únicas nesse processo. A concepção da educação comunitária levou o grupo a decidir pela extinção da função de direção por entender que a gestão precisa aproximar-se de modelos mais comunitários e menos burocráticos e hierarquizados. A própria organização social é quem gere o Projeto Político-Pedagógico e regendo-o educam:

Não são somente os professores e professoras que se responsabilizam diretamente pela educação escolar do nosso povo. Nossa organização interna procura incorporar o maior número possível de membros das comunidades para juntos realizarmos, de forma ampla e com qualidade, as atividades de planejamento e de ação pedagógica. Entendemos que isso é importante porque é a comunidade quem fortalece a luta do povo em todos os aspectos. Para essa relação na escola algumas responsabilidades foram definidas e deliberadas pelo povo e é assim que funciona: questões políticas - pajé, cacique e lideranças de aldeia; questões pedagógicas - coordenador geral, coordenador pedagógico, professor/a, pajés, anciãos, conselho interno, agentes de saúde e secretários. (OIEEIP, 2010, p. 18).

Apesar dessa divisão entre funções políticas e pedagógicas, na prática as decisões nos dois âmbitos são tomadas em conjunto nas reuniões de planejamento semestrais. Os pajés são a presença mais importante e toda decisão conta com a anuência destes. A posição das professoras não está hierarquizada diante da autoridade das lideranças. Ao contrário, são elas as principais articuladoras dessa relação dialógica. Como define Mignolo (2008), um movimento plurilógico.

Penso, todavia, que o desejo por um projeto que se sustenta pela organização social é explicado, em parte, devido ao reconhecimento das realidades históricas distintas entre a geração dos mais velhos e das professoras. Todo o saber que baliza o modelo e funcionamento da organização na Serra do Arapuá subsistiu à diferença no poder por tantos anos. Tal opção no PPP poderia ser qualificada de uma "razão estratégica realista" do sujeito sócio histórico (DUSSEL, 2012), que se desenvolve coletivamente desde a realidade objetiva do povo. Dussel analisa que 0

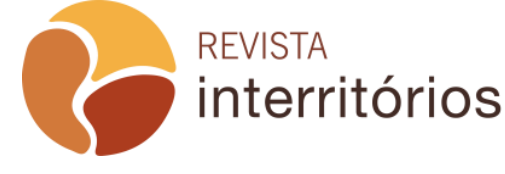


surgimento do sujeito sócio histórico se dá ao efetuar uma crítica autoconsciente do sistema que causa a vitimização. Assim, migra de uma subjetividade passiva para uma subjetividade agente na história.

Essa conceituação da subjetividade libertadora, em Dussel, é uma chave de leitura importante para compreender porque os Pankará elegem a organização sócio política como um conteúdo estratégico dos seus processos educativos rumo à estação de transformação de uma realidade com tantas interdições. Nesse sentido, as professoras e lideranças Pankará arguem que:

O processo histórico de luta vivido no século XIX e XXI pelos Pankará com os fazendeiros e políticos da região, aconteceram em torno de estratégias de luta e resistência para permanência no território e da vivencia das práticas culturais. Após o reconhecimento étnico esses conflitos continuaram, porém, não mais em torno da posse da terra e sim da disputa de poder entre os políticos e não índios da região contra a Organização Social Pankará. Nesse contexto a educação escolar surge como base para a reorganização social, reafirmação da identidade étnica no povo, bem como a formação da consciência política e crítica nos indivíduos da realidade que os cerca. (SILVA; ROSA; SILVA, 2012, p. 1).

A nossa organização é o que nos identifica diante dos brancos. É um direito que a gente tem de ser como a gente é aqui, com nossas histórias, nossos pajés, eu que sou a cacique, com as lideranças da aldeia, a educação, as famílias, as aldeias e o Toré. É através da nossa organização que conseguimos manter firme a luta, porque é na organização que o povo aprende a não obedecer mais ao fazendeiro, o prefeito, vereador, qualquer um que queira oprimir. $E$ quem nos guia são os Encantados. É por isso que toda vez que o prefeito ou o fazendeiro quer nos atacar, eles atacam a nossa organização. Porque eles sabem que aqui é que está a nossa força. (Dorinha Limeira, cacique Pankará, 2013).

A organização é um elemento que aparece nas falas das indígenas e quilombolas diretamente associadas à autonomia do povo, à sua alteridade e ao direito de exercê-las:

Nossa escola passou a integrar a Organização de Educação Pankará, a partir daí alunos e comunidade passaram a ser mais valorizados com sua própria história, professoras da comunidade, autonomia pedagógica, formação continuada diferenciada para as professoras, enfim. Foi uma mudança que vem fortalecendo bastante a nossa identidade enquanto negros/ índios da Tiririca, pois a escola Manoel Miguel passou a ter o papel de formar guerreiros e guerreiras capazes de lutar e reivindicar pelos direitos coletivos dos indígenas e 
"Retomada da Educação Escolar": um estudo sobre

quilombolas. É nesse propósito que os saberes são repassados na escola pois o espaço escolar é formado de identidade étnica quilombola-indígena. (SANTOS SÁ, 2016, p.10).

A observação e a vivência, com os Pankará e Tiririqueiros, dessas questões fazem-me perceber que no processo educativo ensinar a ter compromisso com as lutas empreendidas pelo povo significa "aprender a ser guerreiro e guerreira" na lógica do povo e, consequentemente, isso gera o envolvimento com a organização social.

Então o compromisso é outro tipo de valor que agrega importância à formação de um membro nessa sociedade e tem um significado eminentemente político; a organização dá sustentação para a identidade coletiva e valores que defendem. Ser uma pessoa comprometida e envolvida com o coletivo é um saber alimentado dia a dia nessa sociedade.

Por certo a dimensão pedagógica acolhe o modo específico e coletivo de organizar-se. Entretanto tem entre seus maiores desafios assegurar seus consensos, dissensos e consentimentos sem a interferência do "outro" dominador. Recordemos que a história de resistência dos Pankará e Tiririqueiros para estabelecer uma organização de base coletiva é também a história de violência que os acometeu.

Fanon, ao analisar a violência com a qual se tem afirmado, historicamente, a supremacia dos valores brancos e a agressividade que impregna a confrontação vitoriosa desses valores face aos modos de vida e de pensamento dos colonizados, adverte que o mundo colonial é um mundo em compartimento, no qual se pode observar como o maniqueísmo chegou aos extremos de sua lógica utilizando a violência para garantir a pretensa supremacia dos valores ocidentais/europeus, cristãos e sexistas. Sendo assim, "destruir o mundo colonial não é nem mais nem menos abolir uma zona, enterrá-la no mais profundo da terra ou expulsá-la do território”. (FANON, 2010, p. 57).

Quando eu assumi o cacicado os Carnaubeira da Penha diziam rindo do meu povo: "eita agora quem manda lá é mulher!" ou então " vão ser mandado por uma mulher?". Porque o povo de fora não compreende como funciona a organização aqui em Pankará. Pode ser mulher, homem, jovem, velho, só não pode ser os brancos, só não pode ser quem tá do lado dos fazendeiros, só não pode ser quem cerca a terra e as nascentes de água, só não pode ser quem não tem a ciência do índio. Eu tenho a ciência, sou abençoada pelos Encantos, indicada pela Natureza Sagrada e orientada por meus pajés. E sou mulher sim. No meu povo as mulheres sempre participaram da luta, sempre assumiram um lugar importante na organização. Por isso meu povo me respeita e no que 
depender de mim com meu povo essa Serra vai ser livre. E eu acredito que estamos perto disso, pois veja só: expulsaram meu avô, queimaram a casa de pai e mãe várias vezes, tentaram me tirar do cacicado, mas continuamos aqui, fortes, porque somos organizados. (Dorinha Limeira, cacique Pankará, 2013).

Cacique Dorinha nos ensina que 'educar para o compromisso com a organização social do povo' é investir na criação de uma subjetividade que comporta o desejo de transformar a Serra do Arapuá em um território de vida. Dentro deste universo, orienta as dinâmicas de reprodução social para um futuro próximo de liberdade dentro de casa. É ir "enterrando" ou "expulsando", nas palavras de Fanon (2010), a estrutura social colonial vigente na Serra do Arapuá sem alienar-se, posto que a Colonialidade do Poder recria meios de reproduzir-se e de manter-se.

Notas para concluir: entre a descolonização e a cultura como avatar da escola indígena

Agora é necessário trocar de "pele", obter novos olhos. Trocar de pele como a serpente, mas não a perversa serpente traiçoeira que tentava Adão na Mesopotâmia, mas a "serpente emplumada", a Divina Dualidade (Quetzalcóatl), que "troca sua pele" para crescer. Troquemos a pele! Enrique Dusse ${ }^{33}$

Em minha trajetória como indigenista e antropóloga tenho acompanhando várias experiências e diálogos sobre a escola indígena na região nordeste do Brasil e, em alguma medida, percebo um pensamento predominante no qual a escola, para ser indígena, precisa esforçar-se para substancializar a cultura e tradição do povo. Caso contrário será apenas uma escola para índios. Ocorre que, nessas experiências, a minha percepção é de que a noção de cultura presente nos discursos de técnicos/as e gestores/as das secretarias de educação, e de algumas professoras/es e lideranças indígenas, é simplificadora. Consideram apenas os elementos mais objetivos que caracterizam a diferença. Inserem no currículo componentes que abordam as manifestações do cotidiano do povo, seus costumes, línguas, rituais e história oral para "resgatar a cultura" de forma setorizada, obedecendo sem qualquer inflexão ao disposto na Lei de Diretrizes de Base, no artigo 26, como "parte diversificada" dentro da base nacional comum.

Cabe problematizar que é o Estado, por meio dos órgãos de Educação, que interpreta como "parte diversificada" os conhecimentos e saberes que os indígenas elegem para seu currículo. Há casos, porém, em que os povos

${ }^{33}$ DUSSEL, Enrique. 1492. El encubrimiento del Outro. Hacia el origen Del "Mito de La Modernidad". La Paz: Plural Editores, 1994.

REVISTA interritórios
Interritórios | Revista de Educação Universidade Federal de Pernambuco, Caruaru, BRASIL | V.5 N.9 [2019] 
subvertem essa lógica extraoficialmente; já em outros adaptam-se ao estabelecido por concordarem ou por serem inaptos a perceber as artimanhas do estado colonial etnofágico (DÍAZ-POLANCO, 2005). Interessante notar, de acordo com o autor, como o processo etnófago confunde a todos; ele exalta a cultura, os valores étnicos, defende as relações interculturais, sem, contudo, alterar as estruturas que produzem a diferença no poder. Díaz-Polanco ainda reitera que o Estado, ao apresentar-se como o "defensor" das políticas de identidade disfarça, com sutileza, a etnofagia ao transformar os próprios atores indígenas em promotores da política estatal: eles passam a realizá-la "por sua própria vontade".

Este é um dos problemas, em minha análise, enfrentados pelo movimento indígena nos casos em que a formação das/dos professoras/es passa a ser de responsabilidade exclusiva das secretarias de educação. Observo como algumas formações buscam atender mais demandas do órgão estatal, para disciplinar as/os professoras/es nas técnicas e procedimentos de controle e avaliação de desempenho, ao invés de atender demandas do movimento indígena. Mesmo não podendo deixar de reconhecer todo o esforço dos/das técnicos/as desses órgãos, o que problematizo são as lógicas adotadas.

Podemos aferir na realidade factual os PPP concebidos nos moldes gerencialistas, em cuja estrutura vemos a definição de "visão", "missão", "habilidades e competências"; objetivo geral para "formar sujeitos críticos" 34 . O padrão gerencialista, que ganha corpo na década de 1990, foi pensado como modelo de resolução dos problemas de ineficiência na administração pública e tem sido transposto como sinônimo de qualidade para muitas das escolas indígenas no Nordeste.

Quando as lógicas e concepções do estado esvaziam a capacidade criativa das professoras indígenas, vemos projetos políticos pedagógicos burocratizados e pouco reveladores das racionalidades específicas de cada povo. Pois bem, cabe retomar as contribuições de Bartomeu Meliá quando afirma:

São esses passos suficientes para remontar a corrente da perda da alteridade e recuperar as diferenças? Hoje sabemos perfeitamente que não! A língua com palavras indígenas pode não ser indígena; a adaptação de currículos e conteúdos pode ficar reduzida ao campo do folclórico e do óbvio; os professores podem ser cooptados pelo Estado e pelas instituições, com

\footnotetext{
${ }^{34}$ Para o planejamento das disciplinas que oferto na Unilab "Antropologia da Educação" e "Educação Intercultural Indígena" pesquisei o Projeto Político Pedagógico de várias escolas indígenas no Nordeste e em demais regiões do Brasil. Este exemplo que trago baseia-se na análise e uso que faço destes documentos em sala de aula e nas minhas pesquisas.
} 
efeitos mais destrutivos, precisamente porque parece que já foram satisfeitas as demandas e as exigências dos indígenas. (MELIÁ, 1999, p.14).

O campo de estudos sobre a Educação Escolar Indígena no Brasil confirma a pluralidade de projetos de escola indígena ricos em formulação de pedagogias outras, orientadas a refundar o modelo de escola imposta pelo Estado em seus territórios. Mesmo reconhecendo estes avanços é necessário considerar as contradições e fragilidades inerentes às práticas sociais para revisitar os enfoques e conceitos que se pretendem hegemônicos e colocar em debate os desafios (novos e velhos) de levar a cabo um processo educativo autônomo.

Neste artigo procuramos postular que um projeto de escola indígena pode desenvolver-se para além da cultura como seu avatar, mas como aposta na pluralidade histórica e na luta por autonomia (SEGATO 2007;2012). Por ser um projeto não está isento de contradições; surge a partir das lutas de um povo que decide pelo direito de deliberar sobre seu projeto societário e de futuro a despeito das tentativas de intervenção do Estado e de seus antagonistas. Inclusive deliberar em que medida sua autonomia desenvolve-se por dentro do Estado e na exterioridade deste. Para delinear melhor essa reflexão, me apoio em Rita Segato:

Para defender a autonomia será preciso abandonar os argumentos relativistas e do direito à diferença e substituí-los por um argumento que se apoie no que sugeri definir como pluralismo histórico. Os sujeitos coletivos dessa pluralidade de histórias são os povos, com autonomia deliberativa para realizar seu processo histórico, ainda que em contato, como sempre foi, com a experiência, as soluções e os processos de outros povos[...]. Esta perspectiva nos conduz a substituir a expressão "uma cultura" pela expressão "um povo", sujeito vivo de uma história, em meio a articulações e intercâmbios que, mais que uma interculturalidade, desenham uma interhistoricidade (SEGATO 2012, pp.111-112. Grifos da autora)

Por fim, argumento ainda que reconheço nessa relação dialógica, escola e cultura, a sua importância pedagógica para os processos de reelaboração cultural de povos com intenso contato com a sociedade nacional. Do mesmo modo que argumenta Segato (2012), não podemos dispensar a cultura como conceito antropológico porque compreendo, a partir da observação empírica, que se trata também de um recurso discursivo importante para marcar posições de alteridade em contextos onde a diferença é tratada em termos derrogatórios. A problemática situa-se no esvaziamento dos sentidos da cultura e de seu isolamento em relação a outros processos sociais e históricos indispensáveis para a compreensão situada e fundamentada historicamente

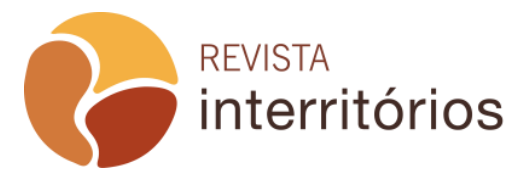


dos significados da Escola Indígena na contemporaneidade. Descolonizar a escola é trocar a pele que a encobriu: troquemos a pele!

\section{REFERÊNCIAS}

ALARCON, Daniela. A forma retomada: Contribuições para o estudo das retomadas de terras, a partir do caso tupinambá da serra do padeiro. Ruris, v.7, nำ, março 2013. Disponível em: https://www.ifch.unicamp.br/ojs/index.php/ruris/article/view/1648. Acesso em: 06 ago 2019.

ALMEIDA, Alfredo Wagner Berno de. Terras de Quilombo, Terras Indígenas, "Babaçuais Livres", "Castanhais do Povo", Faxinais e Fundos de Pasto: terras tradicionalmente ocupadas. $2^{\underline{a}}$ ed. Manaus: PPGSCA-UFAM, 2008.

ANDRADE, Lara. "Nem emergentes, nem ressurgentes, nós somos povos resistentes": território e organização sócio-política entre os Pankará. [Monografia]. Recife: Centro de Filosofia e Ciências Humanas, Bacharelado em Ciências Sociais da UFPE, 2010.

BALANDIER, Georges. Antropologia Política. 2.ed. Lisboa: Presença, 1987.

CARVALHO, José Murilo de. "Mandonismo, coronelismo, clientelismo: uma discussão conceitual." Em: Dados, Revista de Ciências Sociais, Rio de Janeiro, vol. 40, n. 2, p. 229-250,1997. Disponível em: http://dx.doi.org/10.1590/S001152581997000200003. Acesso em: 10 set 2019.

DÍAZ-POLANCO, Héctor. Etnofagia y multiculturalismo. Revista Memoria, número 200, octubre de 2005. Disponível em:

http://sgpwe.izt.uam.mx/files/users/uami/lauv/Etnofagia_y_multiculturalismo_DiazPolanco.pdf. Acesso em 10 set 2019.

DUSSEL, Enrique. Ética da Libertação na idade da globalização e da exclusão. Petrópolis: Editora Vozes, 2012.

FANON, Frantz. Os Condenados da Terra. Juiz de Fora: UFJF, 2010.

GRUNEWALD, Rodrigo de Azeredo. 'Regime de Índio' e faccionalismo: os Atikum da Serra Umã. [Dissertação de Mestrado]. Rio de Janeiro: Programa de PósGraduação em Antropologia da UFRJ/Museu Nacional,1993.

LITTLE, Paul. Territórios Sociais e Povos Tradicionais no Brasil: por uma antropologia da territorialidade. Série Antropologia, n. 322, Brasília: UNB, 2002. Disponível em:

http://periodicos.unb.br/index.php/anuarioantropologico/article/view/6871. Acesso em 18 jan 2018.

LOPES, Luciete; MARCOLINO, Maria da Penha; PEREIRA, Maria do Carmo. A geopolítica e o desenvolvimento sustentável. Descrição socioeconômica e ambiental do povo Pankará. [Especialização em Geografia]. Carnaubeira da Penha: Faculdades Integradas Montenegro, 2011.

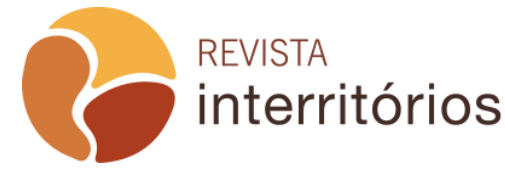


MELIÁ, Bartomeu. Educação indígena e alfabetização. São Paulo: Loyola, 1979.

MELIÁ, Bartomeu. Educação Indígena na Escola. Cadernos Cedes, ano XIX, no 49, Dezembro, 1999. Disponível em:

http://www.scielo.br/pdf/ccedes/v19n49/a02v1949.pdf. Acessado em: fev 2012.

MENDONÇA, Caroline Farias Leal. "Os Índios da Serra do Arapuá": identidade, território e conflito no sertão de Pernambuco. [Dissertação Mestrado]. Recife: Centro de Filosofia e Ciências Humanas, Programa de Pós-Graduação em Antropologia da UFPE, 2003.

MENDONÇA, Caroline Leal. "Guerreiras Indígenas Reunindo as Forças": agência de mulheres indígenas e políticas públicas de educação escolar intercultural. Em: SCOTT, Parry(org.). Educação, Feminismo e o Estado no Brasil. Recife: Ed. Universitária: UFPE, 2016.

MENDONÇA. Caroline Farias Leal. Insurgência política e desobediência epistêmica: movimento descolonial de indígenas e quilombolas na Serra do Arapuá. [Tese Doutorado em Antropologia]. Recife: Centro de Filosofia e Ciências Humanas, Programa de Pós-Graduação em Antropologia da UFPE, 2013.

MIGNOLO, Walter. Desobediência Epistêmica: a opção descolonial e o significado de identidade em política. Cadernos de Letras da UFF - Dossiê: Literatura, língua e identidade, n. 34, 2008. Disponível em: www.javeriana.edu.co/pensar/Rev34.html. Acesso em: out 2011.

OLIVEIRA, João Pacheco de. Uma etnologia dos "índios misturados"? Situação colonial, territorialização e fluxos culturais. Em: OLIVEIRA, João Pacheco de. (Org.). A viagem da volta: etnicidade, política e reelaboração cultural no Nordeste Indígena. $1^{\underline{a}}$ ed. Rio de Janeiro: Contracapa, 1999.

ORGANIZAÇÃO INTERNA DE EDUCAÇÃO ESCOLAR PANKARÁ (OIEEIP). Escola Pankará: memórias do passado, saberes do presente: história, luta, ciência e resistência. Projeto Político Pedagógico, 2007.

ORTNER, S. B. Poder e Projetos: reflexões sobre a agência. EM: GROSSI, M. P. (et alli). Reunião Brasileira de Antropologia: Conferências e práticas antropológicas.

Blumenau: Nova Letra, 2007.

PEREIRA, Fernanda; PEREIRA, Silvia. O Ensino de História nas Escolas Pankará. [Trabalho de Conclusão de Curso]. Caruaru: Centro Acadêmico do Agreste, Licenciatura Intercultural da UFPE, 2012.

QUIJANO, Anibal. Colonialidade do poder, eurocentrismo e América Latina. Em: LANDER, Edgardo (Org.). A colonialidade do saber: eurocentrismo e ciências sociais. Perspectivas latino-americanas. Buenos Aires: CLACSO, 2005. (Colección Sur Sur). Disponível em: http://bibliotecavirtual.clacso.org.ar/ar/libros/lander/pt/Quijano.rtf. Acesso em: ago 2012.

SANTOS SÁ, Alecksandra Ana. Relações de Parentesco entre o Quilombo Indígena Tiririca e o Povo Indígena Pankará. [Especialização em Educação Intercultural no Pensamento Decolonial]. Floresta: Instituto Federal de Educação e Tecnologia do Sertão Pernambucano, 2016.

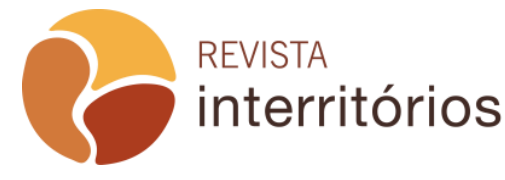


SANTOS, S. Boaventura. Pela Mão de Alice. São Paulo: Cortez Editora, 1995.

SEGATO, Rita. Gênero e colonialidade: em busca de chaves de leitura e de um vocabulário estratégico descolonial, e-cadernos ces [Online], 18 | 2012. Disponível em: https://journals.openedition.org/eces/1533. Acesso em jan 2013.

SEGATO, Rita. Que cada povo trame os fios da sua história: Em defesa de um Estado restituidor e garantista da deliberação no foro étnico. Argüição lida na Audiência Pública realizada em 05/09/2007 pela Comissão de Direitos Humanos da Câmara dos Deputados sobre o Projeto de Lei no 1057 de 2007 do Deputado Henrique Afonso sobre a prática do infanticídio em áreas indígenas. Disponível em: https://cimi.org.br/2007/09/26510/. Acesso em fev 2012.

SILVA, Angelina; ROSA, Elizangela; SILVA, Ericka. Cultura Pankará, currículo e projeto de futuro do povo. [Trabalho de Conclusão de Curso]. Caruaru: Centro Acadêmico do Agreste, Licenciatura Intercultural da UFPE, 2012.

WALSH, Catherine. Interculturalidade crítica e pedagogia decolonial: in-surgir, reexistir e re-viver. In. CANDAU, Vera Maria (Org.). Educação intercultural na América Latina: entre concepções, tensões e propostas. Rio de Janeiro: 7 Letras, 2009.

WOLF, Eric. Encarando o poder: velhos insights, novas questões. Em: FELDMANBIANCO, B e RIBEIRO, G.L (Orgs). Antropologia e Poder. Contribuições de Eric R.Wolf. Brasília: Editora Universitária de Brasília: São Paulo: Imprensa Oficial do Estado de São Paulo: Editora Unicamp, 2003. 